SCHOLARS: Journal of Arts \& Humanities

Volume 3, No. 1, February 2021, pp. 26-33

[Peer-Reviewed, Open Access, Indexed in NepJOL]

Print ISSN: 2773-7829; e-ISSN: 2773-7837

DOI: https://doi.org/10.3126/sjah.v3i1.35356
Central Department of English

Tribhuvan University

Kirtipur, Kathmandu, Nepal

www.cdetu.edu.np/ejournal/

\title{
Performing Arts and BarkaNaach of Dangaura Tharus as Folk Drama
}

\author{
Megh Prasad Kharel \\ Independent Researcher \\ Ghorahi Sub-Metropolitan City-4, Dang, Nepal
}

Corresponding Author: Megh Prasad Kharel,Email: mpkharel@gmail.com Copyright 2021 (C) Author/s and the Publisher

\begin{abstract}
This article examines different elements of folk drama in the BarkaNaach of Dangaura Tharus. It attempts to present the multiple features of the folk drama in the folk community. Based on the basic features of vernacular theatre, the study spotlights the key dramatic elements like ritual rule, context, narrative, stage and setting, characters and semiotic implication, song, dance and language as well as musical instruments and costumes in the presentation of BarkaNaach. The analysis of such drama in the light of elementary facet underlines the multiple sides of folklore as it embodies the cultural identity and value of Tharus. In doing so, I also argue that its theatrical aspects like plot and storyline are not unfamiliar to the rural farmers. Consequently, the study concludes that ritualistic performance of folk drama does not bring the unexpected happening, but it is repeated with their routinized act of cultural memory whatever performed in the past days of the ancestral force.
\end{abstract}

Keywords: Folk drama, performance, cultural identity, routinized act, cultural memory

\section{Introduction}

Dangaura Tharus, who have the original home of Dang valley in the western Tarai region, are one of the leading ethnic groups in the overall community of Tharus in Nepal. They have their own cultural and linguistic identity, and also seem distinctive from other subgroups of Tharus such as Desaura, Rana, Chitawniya and Kochila. They are quite rich in the folk literature and performing arts. However, their different folk literary genres reflect certain "collective consciousness" of the primordial ethnicity in a particular geographical setting (Diwasa, Folklore 152). Among various literary genres of folklore, folk drama is their one of the best performing arts as they perform with certain ritual rule (bidhibidhān) on the occasion of different festivals and socio-cultural events. GaiyāBehrnā, MaghāLotnā, KathghoriNaach and BarkaNaach are the famous folk dramas, which are performed with musical dance, acting, staging and many other features of vernacular based dramaturgical enactments in their locality. 
Performing Arts and BarkaNaach of of Dangaura Tharus as Folk Drama 27

Folk drama in the indigenous communities portrays their lifeblood because it is a cultural expression of the life and conviction. Moreover, it also reflects the cultural feeling and emotion of the people with the vernacular type of musical skill, acting and custom. In fact, the "dance, music and acting are equally important for folk drama which make the performance more entertaining and live and presents the natural way of life" (Diwasa, "Dhimal" 60-61). Relying basically on the peasantry way of vernacular life, as Diwasa claims, folk drama "denies any kind of artificiality in the performance, story or plot and for stage decoration" (61). Therefore, "it is full of natural way of life, the natural feelings, emotions and the sentiments of the folk people and it is performed on the natural folk setting” (61). In particular, the rural farmers are involved to perform the content of its folk materials.

The performers use the space for the performance that is a common stage of villagers as they have no any concern on the modernized, advanced and artificial type of decorated stage to perform their folk materials. In addition, any folk drama as no written property of the individual writer, but it is a "developed by the folk community" and also "known as the property of the folk community" (9). In general, folk drama includes "the means of dramatic arts" like costuming, ritual enactment and pageant with the artistic enjoyment, which reinforces the social communication among the members of folk group (Green 844). Regarding the folk level of its cultural performance, Anne C. Burson argues, "Folk drama is seen as an activity which has roots in the usually distant, rural past, and which often seems somewhat out of place in a contemporary cultural context. In addition, folk productions are considered to have basically fixed texts which were handed down unchanged from year to year and generation” (305). In other words, innovative activities of folk performance based on the theatrical events are created and practiced since the primordial time to the present days. At the backdrop of the Nepali socio-cultural context, folk drama of BarkaNaach of Dangaura Tharus has been created and performed by the communities of Tharus for centuries.

\section{BarkaNaach as Fold Drama: A Descriptive-Analysis}

Chudamani Bandhu, a folklorist, discusses the following basic seven elements of folk drama in the Nepali socio-cultural context: Guruparamparā (guru tradition), bidhibidhān (ritual rule), storyline (narrative), staging (folk theatre), characters, song and dance, and musical instrument ${ }^{1}$ (Nepali 262-4). Moreover, another folkloristic critic Kapildev Lamichhane also emphasizes various elements in folk drama such as narrative, composition or emotion, character and characterization, dialogue, language style, staging, acting, costume, music and rhythm (355-59). These elements suggest that folk drama should reveal the folkloristic style with the ritual enactment in the locality of the community. Relying on above-mentioned major components, this article tries to explore how the BarkaNaach of Dangaura Tharus has used various elements of the folk drama, which also reinforces the cultural identity, value and representation of aparticular community. In other words, the research method primarily follows the analytical and descriptive elements of the folk drama. Likewise, the study also aims to apply the somewhat field visit conversation with performer and photo clip of its ritual enactment.

\footnotetext{
${ }^{1}$ The ideas and opinions from Nepali writings used in this article are my own translation in English.
} 


\section{Ritual Rule and Religious Connection}

To perform the folk drama of BarkaNaach, the performers need to follow the certain bidhibidhān. Thus, Govinda Acharya asserts that this vernacular drama is basically "the staging of the folk dances based on their deities" and, therefore, it needs to follow "various strictly religious and ritual rules" (161). Without ensuring certain ritual rules, folk religious belief and conviction does not permit to perform its acting. Therefore, certain rules in the unscripted practice are made to perform in the vernacular stage and theatre of their space. At first, Guraipuja (a type of ritual enactment) is an obligatory to start the BarkaNaach. Different Gurwās (priests/shamans) like Deshbandhyā, Kesaukā and GharGurwā are gathered at the courtyard of Matawā (chief of the villagers) and they also perform various ritual activities of Guraipujā. Deshbandhyā and KesaukāGurwāre cite the mantra whereas Matawā worship to their local deities. Indeed, Guraipujā is performed in the dancing stages of Matawāas courtyard and bhuinyārthān, the place where local deities are kept with wooden and stone-signs in different designs. During the Gurai pujā, Gurwā also takes the promise to offer the animal and chicken sacrifices to their local deities after the successful completion of BarkaNaach.

\section{Context and Performance}

The context of performing BarkaNaach is related to the physical setting and social situations of Tharu. Indeed, the context "refers to anything and everything that surrounds a text and performance” (Sims and Stephen 137). The performing context highlights the cultural system that creates the relationships and interactions among the members of the Tharu community. It is connected with "the specific time period in which the performance occurs as well as the details of the place and circumstances in which the events takes place" (137). Moreover, Tharu people of Dang-Deukhuri perform the folk version of Mahabharata "to worship deities and Pāndavas for general well-being and good harvesting" and, therefore, its acting "has kept the Tharu worldview intact" (Bandhu, Aspects 126). If its dramatic dance is performed in their villages, the folk conviction in their community is that it reinforces to "maintain happy, peace, prosperity and wide joviality" due to the blessing of their local deities (Acharya and Tharu 61). It is common that dramatic performance of BarkaNaach is started during the Dasya (Dashain) festival. In the same way, it can alsobe performed between their festivals of HāryāGurai (festival often occurs in July/August) to DhuryāGurai (festival often takes place in May/June). Their local musical instruments are needed to play for its different dramatic events. Therefore, Hārya Gurai is obligatorily needed to perform because it is not allowed to play the local musical instruments after the ritual performance of DhuryāGurai. In fact, BarkaNaach is difficult to perform every year due to the gradual disappearing of folk skilled performers.According to its traditional rule, it is performed in every five years, which is known as patti-fern $\bar{a}^{2}$. If different governmental sectors, the NGOs and INGOs support the community, they can perform anytime exceptthe timeperiod of DhuryāGurai to HāryāGurai.

${ }^{2}$ I talked with Chandra Prasad Chaudhary during my field study of BarkaNaach in October 2019 at his Jalaurā village of Dang valley. 
Performing Arts and BarkaNaach of of Dangaura Tharus as Folk Drama 29

\section{Narrative and Its Significance}

The narrative of BarkaNaach is a significant part of folk epic Barkimār (Big War) in theTharu community. Barkimār is a collection of stories that are taken from the Mahabharata. It tells the story of royal clan of Kuru in the ancient India. In other words, it covers the narrative of familial enmity between Pandavas and Kauravas for the ruling authority in the Kuru kingdom. Moreover, it is a folk version of Mahabharata and most of its narratives are based on its classical story. Its narrative tells us that the heroic characteristics are centered on Bhima among "the all the Pandavas" because "it is the closest to the Tharu although the Tharus worship and respect all five brothers" (Meyer and Deue 14). The veneration of Bhima shows that he "succeeds in hitting the eye of the bird and carrying away Princess Draupadi to become the wife of Pandavas." In contrast, the classical version has the role of Arjun to hit the target of fish-eye at the time of Draupadi swayamvara. In the same way, the classical version includes different eighteen parvas (chapters), but the Tharu version involves twelve paidhār (chapters). These twelve chapters are named as Samrauti, LakhāgirakPaidhār, JātiyakPaidhār, RāuBedhakPaidhār, PashawarakPaidhār, BanabāsakPaidhār, GharbāsakPaidhār, HatiyakPaidhār, KichakakPaidhār, SushārmakPaidhār, BarkimārkoPaidhār and SworgārohanPaidhār. While performing the BarkaNaach, the performers sing the song from these twelve chapters according to the need of different serial events and time contexts.

\section{Stage and Setting}

Unlike the modern drama of artificial theatre, folk drama of BarkaNaachis performed in anopen space. Such drama is performed according to the vernacular setting and scene. Thus, performing stage of folk drama is open and audience can freely sit and stand on any direction according to their choice. It does not need artificial and formal decoration in the performing stage like in the modern drama for its acting of performers. It has natural performance to show their folk skills based on the folk contents embedded in the rural version of Mahabharata. Without theartificial light arrangement, it can be performed in the open space of villagers in the day time as well. For the ritual performance of Guraipujā, bhuinyārthān and agnā (courtyard) of Matawā is chosen. Similarly, the open spaces like agna and khenwa (threshing floor) of rural people are appropriate for singing and dancing. According to Chandra Prasad Chaudhari, it becomes easierto perform the dramatic events of BarkaNaach where Matawā and Gurwā system is running as both Matawā and Gurwācan easily manage the ritual and local managerial activities in their village. On the one hand, the stage of bhuinyārthān is used for worshipping local deities and singing samrauti. On the other, open spaces of agna and $k h e n w \bar{a}$ of the villagers are chosen to show the multiple dancing items and steps based on the BarkaNaach. Thus, the setting and arrangement of the scenes in its different steps ofenactments need their folk knowledge and quality rather than the high attitudes based creative impulse of modern knowledge and perception. 


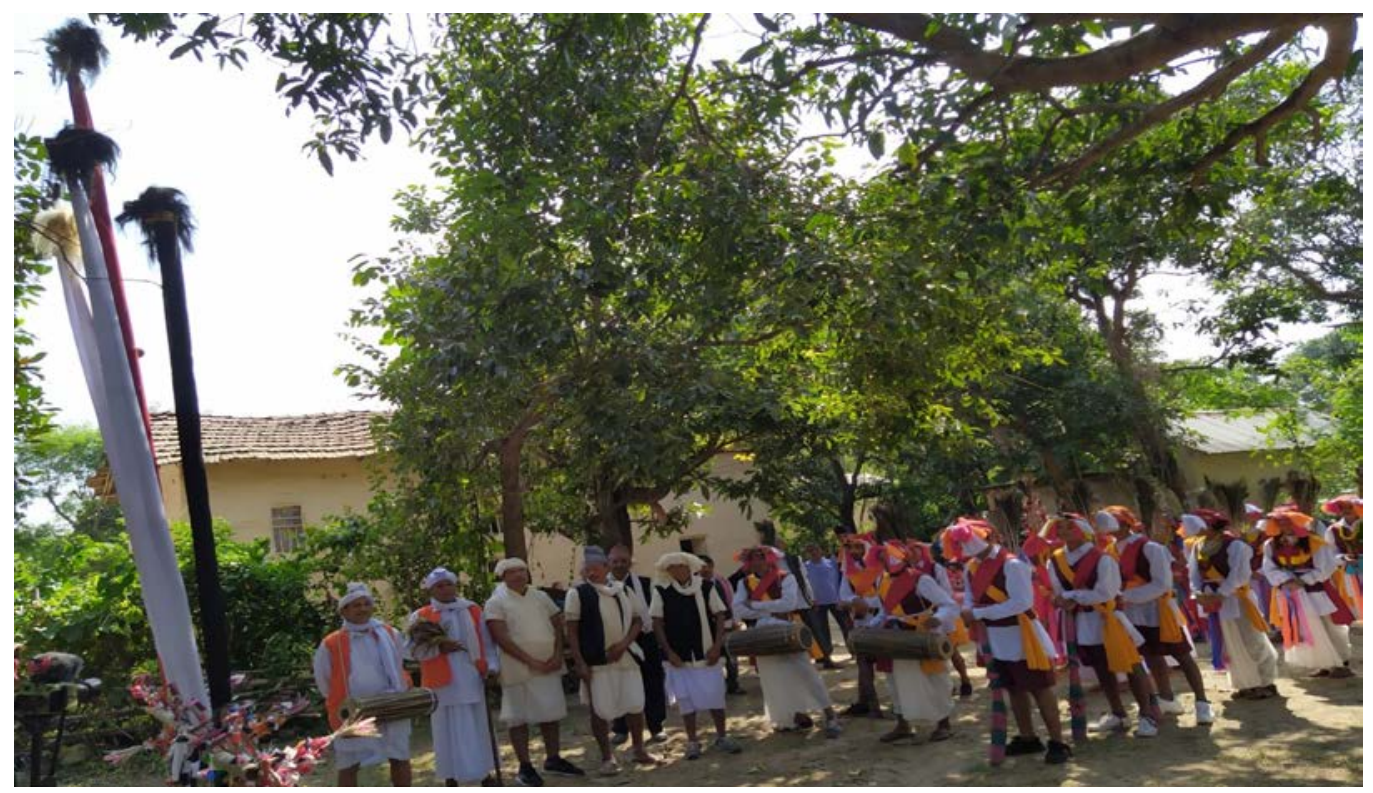

Fig. 1: The performers acting out the folk drama of BarkaNaach at the courtyard of Matawā on October 17, 2019 in Jalaurā village of Dang valley. Photo: Researcher

\section{Characters and Symbolic Implication}

The performers of BarkaNaach represent different characters based on the narration of Barkimār . Each performer represents at least one character of the narrative. The performers have the representative type of symbolic features as they play the role of their physical structure and quality that are explained in the story of Mahabharata. The actors who are selected for different roles must have the substantial role as far as they play to perform the vernacular enactment. Among the performers, most of them have more important roles and they are presented to express the voice and attitude ofdifferent characters. Among the performers, five characters are Arjuns, who play the role of singing the song. Five performers are dressed in $j \bar{a} m \bar{a}$ (local dress) and represent Yudhishthir. Six performers are Bhewān (Bhīma), who bring the wooden-hammer (mungrā) in their hand to show the weapon of mace of Bhimma during the war-time of Kurukshetra. The appearances of Bhīma perform the folk dance of mungrānāc (hammer dance) using the wooden hammer in their hand. Five performers in the dress of females are Durpati (Draupadi) and they also dance in the group. Moreover, five males in the dress of dhoti, shirt and half coat represent Sahidev Pandit (Sahadev). Three to five performers in the costumes of males represent Nakurān (Nakul) who play the role of playing the tom-tom. Similarly, Dronacharya and BhishmaPitamaha are in the role of Deshbandhyā and Kesaukā Gurwā. In the meantime, Swānge is a unique character who wears skull in the head and bamboo-penis in the organ of pelvic cavity. Swānge is the representative of both Mahadev and Krishna. Matawā and Matiny $\bar{a}$ (wife of Matawā) are also important performers who seem additional as such characters are not included in the classical Mahabharata. Matawā plays the managerial role and involves inthe ritual performance of Guraipujā. As a wife of Matawā, Matinyā sets the light of akhanda-jot (unceasing earthen lamp) and worships the Shiva-linga (Shiva-penis) of Swānge. Thus, each performer represents different characters that are mentioned in the story of Tharu Mahabharata. 
The images in BarkaNaach leads to the cultural meanings practiced in different socio-cultural sites. In a semiotic meaning, a sign is anything that stands for something else because any sign stands for an object or a concept. The interpretation of semiotic aspect in the folk drama symbolically reinforces to unveil the cultural meanings of acommunity. Emphasizing the semiotic aspect of the object, Daniel Chandler asserts that "signs take the forms of words, images, sounds, gestures and objects" (2). The performers, who participate in its different steps of ritual performance, stand for various characters of Mahabharata. Consequently, the performers are symbolic implications of Arjun, Dharma Judhisthil (Yudhisthir), Bhewān (Bhīma), Durpati (Draupadi), Nakurān (Nakul), Sahidev Pandit (Sahadev), DesbandhāGurwā (Dronacharya), KesuakāGurwā (BhishmaPitāmaha), Swānge (Bramhā and Krishna) in the folk drama. The 'rāu bird' is performed by the folk actors as it symbolizes the hitting target to the 'bird' by Bhima at the Draupadi swayamvara. Besides, five erected bamboo poles are put in the performing stage and each pole symbolizes King Hinautā (Himalayan king), Yudhisthir, Duryodhan, king Virat and Draupadi respectively.

\section{Song, Dance and Language}

The performers, especially five males of Arjun, sing the content of Barkimār while performing its ritual dance. In this performance, Barkimār is in the couplet form that contains the folk narrative of Pandava brothers. The performer group of Arjun sings different chapters of its couplets according to the need of time and context. The section of samrauti (opening song) is sung by Gurwās, singers, dancers and all the performers. But the rest of samrauti segments or its eleven paidhār are sung by only the five males of Arjun. Moreover, the BarkaNaach involves different musical folk dances like jhumrānāch, chhokrānāch and hurdingyānāch. In the meantime, it also involves twenty two khwāt (rhythms) types of different musical dances. While performing the BarkaNaach, sometimes it involves dances with singing and sometimes it is also performed with only playing the musical instruments. The song and dialogue what they use is in their own mother tongue. Their own language is the medium to express the performing art of folk drama, which reinforces to preserve the cultural heritage of Tharus.

\section{Musical Instruments and Costumes}

The folk drama of BarkaNaach uses different folk musical instruments like mandrā (tom-tom), majirā (small cymbal) and jhāli (large cymbal). Mandrā is especially played by the three to five representative of Nakurān and majirā and jhāli are used by other performers. At that time, performers wear local dress and ornament of Tharus. The costume of jāmanand pagyā (crown) is worn by the five persons of Yudhishthir. In the same way, the team of Draupadi wears blouse, cholyā, lehang $\bar{a}$ and also different items of local jewelries such as taryā, kakari, metaki, churyā, bijāt and sutyā. Moreover, they also have the feathers of peacock in the backside of the head. Other male characters wear Tharu local dresses like dhoti, shirt, paint and half-coat. Wearing the varieties of costume and jewelry makes them attractive when they come to the performing stage. Unlike the use of modern musical instruments and costumes, they use simple and natural things that the folk people can simply play and wear. 
Performing Arts and BarkaNaach of of Dangaura Tharus as Folk Drama 32

\section{Conclusion}

The analysis on the Barka Naach in the light of elementary features unveils its multiple aspects. In the beginning, the folk drama is not written by any individual, but itis living in the oral tradition in the community of Dangaura Tharus for many centuries. The song and dialogue are prepared in the Tharu language and, thus, it is orally transmitted from one generation to another. When they practice in their own language, they find their own ethnic color of the locality. In the same way, dresses and jewelries they wear during the time of performing art of folk drama provides their own cultural identity, value and representation. They also use local musical instruments for their musical song and dance for entertainment, sharing the cultural memories of the past days.

The performing stage and setting is open and natural as the audience can watch and evaluate the performance according to their own choice of the direction. Indeed, the stage scene and setting is quite natural and common that reflects the life of Tharus because it does not involve the modern, advanced and artificial theatre. The open spaces like courtyard of Mataw $\bar{a}$ and threshing floor of the villagers are culturally significant to share the past memories and knowledge of the ancestors. In addition, bidhibidhān of performing the folk drama binds the society in a certain folk conviction. On the one hand, the performance of the folk drama also embodies the semiotic implication of Tharu Mahabharata. The performers, $r \bar{a} u$ bird, five erected bamboo poles represent different characters and narrative events. On the other hand, the audiences are familiar with its narrative of the folk drama and, consequently, there cannot be found excessive curiosity in the development of the storyline and its plot because story and ritual activities in the theatrical site is not unfamiliar. However, the performance of folk drama highlights "the maintenance of a tradition through exact duplication of fixed activities" and it is also "an inherently strategic reproduction and valorization of tradition" (Bell 123). Consequently, the ritual performance of such vernacular performance does not bring such unexpected happening and actions in the concluding time.

\section{Acknowledgements}

I am grateful to the University Grants Commission (UGC), Nepal for providing the $\mathrm{PhD}$ Fellowship and Research Support Grant 2074-75BS for this research.

\section{Works Cited}

Acharya, Govinda. RāptikoLoksāhitya. Pairavi Publication, 2007.

Acharya, Govinda and Ashok Tharu. Ghorāhiko Tharu PradarshankāriKalā. Ghorahi

Sub-Metropolitan Office, 2020

Bandhu, Chudamani. NepaliLoksāhitya. Ekata Books, 2014.

---. Aspects of Nepalese Folklore. Nepal Academy, 2016

Bell, Catherine. Ritual Theory, Ritual Practice. Oxford UP, 2009.

Burson, Anne C. "Model and Text in Folk Drama." The Journal of American Folklore, vol. 93, no. 369, Jul-Sept 1980, pp. 305-316.

Chandler, Daniel. Semiotics: The BASICS. Foundation Books, 2003.

Diwasa, Tulasi. "Dhimal Folk Drama.” Discourses on Folklore, edited by Tulasi Diwasa, Abhi Subedi and Taramani Rai. Nepali Folklore Society, 2015, pp. 60-72. 
---.Folklore and Folklife Study: A Survey of Living Cultural Heritage of Nepal

Publication 6, translated by Bal Ram Adhikari. Field Researchers Acharya,

Govind et al. Kathmandu. Edited by Tulasi Diwasa and Govinda Raj Bhattarai.

Nepali Folklore Society, 2009.

Green, Thomas A. "Towards a Definition of Folk Drama.” The Journal of American Folklore, vol. 91, no. 361, Jul. - Sep., 1978, pp. 843-850.

Lamichhane, Kapildev. LoksāhityaSiddhānta. Nepal Academy, 2020.

Meyer, Kurt and Pamela Deuel, editors. Mahabharata: The Tharu Barka Naach.

Translated by Dinesh Chamling Rai and illustrated by Ashok Tharu. Himal

Books, 1998.

Sims, Martha and Martine Stephens. Living Folklore: An Introduction to the Study of

People and Their Traditions. Utah State UP, 2005. 